\title{
Slavery and Its Transformations: Prolegomena for a Global and Comparative Research Agenda
}

\author{
MATTHIAS VAN ROSSUM \\ International Institute of Social History (IISH), Amsterdam, The Netherlands
}

\section{SLAVERY REVIS I T E D}

In public and academic domains, the history of slavery is still commonly understood through the lens of "classic" slavery in the early modern Atlantic, the nineteenth-century United States, and the Greco-Roman world. The majority of people throughout history who faced conditions of slavery, however, did not live in these classic slavery societies, but in societies with a much wider range of slavery regimes. This was the case before the abolition of the slave trade and legal slavery, especially in the early modern Indian Ocean and Indonesian Archipelago worlds where commercial or chattel slavery systems coexisted with a variety of other regimes. It remained the case after the abolitions, with the continuation of informal "modern" forms of slavery that today characterize the lives and working conditions of an estimated 40.3 million people, again particularly in South and Southeast Asia. ${ }^{1}$

The focus on "classic" formal slavery has in some ways limited our understanding of the adaptable and persistent nature of slavery regimes and their trajectories of development. The definitions developed for these classical histories have reinforced the often implicit and sometimes explicit assumption that the Atlantic history of chattel slavery was largely different and isolated from the wider histories of informal and also "modern" slaveries. This has de-historicized these other, informal forms of slavery as static and unchangeable; in the words of Michael Zeuske, it has led to "smaller slaveries" being "overlaid by hegemonic slaveries" and "conceptualized as "special forms." "2 This has obscured our understanding of

\footnotetext{
1 International Labour Office, Global Estimates of Modern Slavery: Forced Labour and Forced Marriage (Geneva, 2017).

${ }^{2}$ Michael Zeuske, "Historiography and Research Problems of Slavery and the Slave Trade in a Global-Historical Perspective," International Review of Social History 57 (2012): 87-111, 106.
} 
the wider historical trajectories of different forms of slavery as they developed across the globe. It long allowed perceptions of the history of slavery to dominate that conceptualized its development in linear fashion, from an Atlantic expansion of slave trade and slavery to "enlightened" abolitions-in short, from "unfreedom" to "freedom."

Such linear conceptions are increasingly being critiqued by scholars who argue that we need to develop perspectives that account for the coexistence, interaction, decline, and emergence of different forms of slavery. ${ }^{3}$ There is a growing academic awareness of the need to break away from these classical confinements in order to develop more global and encompassing approaches that can better make sense of slavery's long and complex history. ${ }^{4}$ There have been important advances in the rich historiography of Atlantic slavery, and in the expanding scholarship on slavery and slave trades in other parts of the world, but the shift remains incomplete. Though new key concepts of slaving and availability are gaining ground, the wider field of slavery studies has been pointing toward new horizons and proclaiming new dawns more than we have actually, systematically explored them. In 2012, Michael Zeuske called for the "analysis of slavery" to "be replaced by the history of slaveries, or of actors in these slaveries, in the tradition of 'small' and kin slaveries, which extend up to the present." So far, this call has not yet been taken up energetically, although we can take hope from the fact that it is apparent in the agendas of some recently developed research centers. ${ }^{5}$ Thus, although global slavery studies stand on the shoulders of giants, from Nieboer to Patterson, in some respects we have only begun to develop a truly global and encompassing approach, one that addresses not only the enormous variety of slavery forms, but also slavery's adaptability and persistence, from earliest times to the present.

This article aims to contribute to the development of approaches that will improve our understandings of slavery as a persistent social and societal phenomenon from global and long-term perspectives. It explores what can be gained by reversing the dominant perspective, to develop an analytical framework and method that will allow us to integrate and compare the

${ }^{3}$ E.g., Ulbe Bosma, The Making of a Periphery: How Island Southeast Asia Became a Mass Exporter of Labor (New York, 2019); Christian G. De Vito, Juliane Schiel, and Matthias van Rossum, "From Slavery to Precarity? Labour History Revisited, and Beyond," Journal of Social History 54, 2 (2020): 644-62; Matthias van Rossum "Global Slavery, Local Bondage? Rethinking Slaveries as (Im)Mobilizing Regimes from the Case of the Dutch Indian Ocean and Indonesian Archipelago Worlds," Journal of World History 31, 4 (2020): 693-727.

${ }^{4}$ N. Lenski and C. M. Cameron, eds., What Is a Slave Society? The Practice of Slavery in Global Perspective (Cambridge, 2018); Michael Zeuske, Sklaverei: Eine Menschheitsgeschichte von der Steinzeit bis heute (Reclam Verlag, 2018); S. Conermann et al., "Objective: The Cluster of Excellence 'Beyond Slavery and Freedom,"' Bonn Center for Dependency and Slavery Studies, https://www.dependency.uni-bonn.de/en/program/about (accessed 1 Aug. 2019).

5 E.g., The Bonn Center for Dependency and Slavery Studies (BCDSS). 
experiences of slavery "outside" of the Atlantic into a global history of slavery. That is, I argue that we need to reverse our perspective from that of the formal to that of the informal, from the Atlantic to the rest of the world, and away from binary understandings toward ones that are more connected and historicalcontextual.

I will begin by examining the possibilities for, and existing perspectives on, such a global approach and engaging the crucial but often glossed-over distinction between formal and informal regimes of slavery. I then take stock of the growing body of work dealing with slavery, especially in the Indian Ocean and Indonesian Archipelago worlds, to consider what can be gained by incorporating a wider spectrum of historical "slaveries" into our analyses and (re)conceptualizations, as Zeuske has rightfully argued for. This underscores the point that in order to make sense of the highly diverse, adaptable, and persistent nature of slavery we must develop a more systematic comparative agenda that lays the basis for a consistent rethinking of slaveries' forms and developments. A third section of the article reflects upon what we can gain from renewed comparisons to explore the manyfaceted, persistent history of slavery before, after, and beyond the transAtlantic slave trade.

The fourth and fifth sections propose contours for a global and connecting approach for this comparative endeavor. They lay out the first steps toward an analytical model for rethinking the history and presence of slavery by analyzing slavery regimes and their trajectories through both contrasting comparisons and global connections. The development of such a model requires, first, that we understand both the commonalities and the distinguishing features of different forms of coerced labor regimes, or coercive asymmetrical dependencies. Different forms or regimes did not exist in isolation, but were connected and impacted by their interactions, one of the most important of which was via slave trade - the coerced transportation of people. Secondly, we need to account for these connections by looking at interactions and external impacts. These connections, in turn, remind us that neither the classic nor the smaller slaveries were stagnant, self-contained, or unchangeable. Over time, they developed and adapted along different paths, continuously influenced, again, by their interactions. Thirdly, the focus proposed here, on trajectories of slavery regimes, can help us integrate comparative and connecting aspects with their spatial and temporal dimensions.

To enhance our understanding of slavery, we need to undertake a more inclusive, open investigation into the broader spectrum of slavery regimes. We must take an inductive approach that incorporates observations from indepth, source-based analyses and that systematically compares slavery regimes to understand their characteristics, differences, and commonalities. We should avoid static units of analysis and top-down approaches and 
instead consider slavery regimes at the most localized level and in their historical contexts. We should reassemble our knowledge from the ground up by mobilizing sources and observations that provide insight into the everyday realities of how different regimes functioned and how they were enforced and challenged. The histories of these different regimes need to be scrutinized over the longue durée and through multiple time frames, while also accounting for external influences and especially how different regimes were connected and interacted.

The approach advocated here can provide a basis on which to investigate how and why local formal and informal regimes of slavery developed along specific trajectories and how these multiple trajectories influenced long-term global historical transformations of formal and especially informal forms of slavery. This will allow us to move beyond dominant models of "classic" and Atlantic histories of slavery, not by dismissing them but by inverting our academic focus in such a way that we can reassemble our knowledge of the diverse range of local cases and bridge the current divides between historiographies of slavery across the globe, especially, as emphasized in this article, in early modern South and Southeast Asia. The broader goal is to contribute to a larger breakthrough in our understanding of slavery by developing an approach to guide future research, collaboration, and comparative analysis. For the field of (global) slavery studies, the approach will shed new light on key debates about the perceived unique natures or the comparability of slaveries in the Indian Ocean and Atlantic worlds, how the slave trade transformed slavery regimes, and the heterogeneous yet global nature of slavery. Beyond these more disciplinary concerns, this is important for considering how we might push forward "global history" scholarship that navigates between deeply rooted differences in regionalized explanations and scholarly traditions and the dangers of overly top-down, flattening, or universalistic global historical approaches.

\section{TOWARDS A NEW GLOBAL HISTORY OF SLAVERY}

Understanding the many faces of slavery, while accounting for both the commonalities and distinguishing features of different forms of coerced labor, has been an ongoing, much-debated challenge. Such are the difficulties in creating analytical models that both differentiate and unify, that some scholars have concluded that "no single definition has succeeded in comprehending the historical varieties of slavery or in clearly distinguishing the institution from other types of involuntary servitude." ${ }^{.6}$ It is difficult to do justice to the rich tradition of slavery scholarship over the past century and a half, but three influential models stand out.

${ }^{6}$ D. B. Davis, The Problem of Slavery in Western Culture (Oxford, 1988), 32. 
First, in line with the work of Moses I. Finley, the five "slave societies" of ancient Greece and Rome, modern Brazil, the Caribbean, and the U.S. South have been set apart from other "societies with slaves," based most importantly on the fundamental importance of slave labor for those economies. ${ }^{7}$ Despite its influence, scholars have increasingly recognized that this model is too simplistic and needs reevaluation. ${ }^{8}$ A well-developed comparative scholarship on American and classic slavery has greatly advanced insights into "the European background to Atlantic slavery" and "the novel features of Atlantic slavery's exploitative capitalist system." But it seems time to ask what happens when we take these questions beyond the horizons of the Atlantic world and formal slavery regimes. ${ }^{10}$ For example, it has been recently argued that we should also understand "the slave-based economies in Island Southeast Asia" in terms of their "engagement with the global market [as] marked by a diversity of trajectories" in relation to colonialism and capitalism. ${ }^{11}$

In a second influential model, the many variants of coerced labor are analyzed through the lens of the single broad category of "bondage."12 Its advantage is that it brings to the fore commonalities and ambiguities across the wide spectrum of slavery, bondage, and labor coercion. This approach stands alongside a third model in which different coerced-labor regimes are analyzed through contrasting comparisons, which has the advantage of drawing out differences but has often reinforced perceived dichotomies of slavery versus serfdom, or European versus Asian slaveries. ${ }^{13}$ The difficulty here is that despite clear commonalities between varieties, differences between them clearly do matter from analytical as well as contemporary standpoints, and yet the differences are not clear-cut. Forms of slavery could extend to variations of caste and land-based slavery that, in turn, bore similarities to corvée and serfdom regimes, while all of these regimes at times allowed for hiring and selling subjects in ways comparable with commodified slavery. ${ }^{14}$ The takeaway is that we need to move beyond

7 M. I. Finley, Ancient Slavery and Modern Ideology (New York, 1980).

8 P. Lovejoy, Transformations in Slavery: A History of Slavery in Africa (Cambridge, 1983); Zeuske "Research Problems of Slavery"; Lenski and Cameron, What Is a Slave Society?

9 E. Dal Lago, "Comparative Slavery," in Mark M. Smith and Robert L. Paquette, eds., The Oxford Handbook of Slavery in the Americas (Oxford, 2010), 664-84.

${ }^{10}$ E. Dal Lago and C. Katsari, "The Study of Ancient and Modern Slave Systems: Setting an Agenda for Comparison," in E. Dal Lago and C. Katsari, eds., Slave Systems: Ancient and Modern (Cambridge, 2008), 3-31.

11 Bosma, Making of a Periphery, 68.

12 A. Stanziani, Bondage: Labor and Rights in Eurasia from the Sixteenth to the Early Twentieth Centuries (New York, 2014); A. Reid with J. Brewster, eds., Slavery, Bondage, and Dependency in Southeast Asia (St. Lucia, 1983); A. Reid, "'Slavery so Gentle': A Fluid Spectrum of Southeast Asian Conditions of Bondage," in N. Lenski and C. M. Cameron, eds., What Is a Slave Society? The Practice of Slavery in Global Perspective (Cambridge, 2018), 410-28.

13 M. L. Bush, Serfdom and Slavery: Studies in Legal Bondage (New York, 1996).

14 David Moon, The Abolition of Serfdom in Russia (London, 2014). 
perspectives that either compartmentalize or blur different forms of slavery and instead strive to understand its versatility and persistence. And this effort must consider not only the histories of regimes of formal slavery, or the "hegemonic" or "great" slavery traditions of Roman and Islamic law, but also those of the "smaller" kinship and informal slaveries across the world. ${ }^{15}$

The renewed attention paid to the history of slavery in recent decades urges us to reconsider several divisions and gaps that have developed. Within the Atlantic, attentions have expanded beyond North America and the Caribbean to the history of slavery in Africa ${ }^{16}$ and the multiple slavery connections and experiences in the southern Atlantic. ${ }^{17}$ Important historiographic turns have shifted the focus to "urban" and "borderland" spaces and have encompassed broader variations in slavery, control, and resistance in the Atlantic world. ${ }^{18}$ Scholarship on West Africa, in particular, has made two important contributions: First, it has stimulated a perspectival shift from seeing slavery as an institution to understanding slaving as a historical practice. ${ }^{19}$ This has inspired research that tries to understand the dynamics of slavery within different contexts ${ }^{20}$ and looks more closely at the impact, regulation, and contestation of enslavement and enslavebility. ${ }^{21}$ Second, this scholarship has called for understandings of the impact of slave trade on local slavery regimes, and of the "trajectories" of change that slavery underwent under colonial rule and especially after abolition. ${ }^{22}$

These advances have underscored that slavery is not a static phenomenon, and they indicate the importance of understanding not only why slavery occurred, but also, through more comparative and contextualized approaches,

15 Zeuske, "Research Problems."

16 Suzanne Miers and Igor Kopytoff, eds., Slavery in Africa: Historical and Anthropological Perspectives (London, 1977); Lovejoy, Transformations; R. Law, S. Schwarz, and S. Strickrodt, Commercial Agriculture, the Slave Trade and Slavery in Atlantic Africa (Rochester, 2013).

17 H. S. Klein and F. V. Luna, Slavery in Brazil (Cambridge, 2010); W. Hawthorne, From Africa to Brazil: Culture, Identity, and an Atlantic Slave Trade, 1600-1830 (Cambridge, 2010); D. Richardson and F. Ribeiro da Silva, eds., Networks and Trans-Cultural Exchange: Slave Trading in the South Atlantic, 1590-1867 (Leiden, 2014); A. E. Dalrymple-Smith, Commercial Transitions and Abolition in West Africa 1630-1860 (Leiden, 2019).

18 Sylviane A. Diouf, Slavery's Exiles: The Story of the American Maroons (New York, 2014); Mary Niall Mitchell, "Lurking but Working: City Maroons in Antebellum New Orleans," in Marcus Rediker, Titas Chakraborty, and Matthias van Rossum, eds., A Global History of Runaways: Workers, Mobility and Capitalism 1600-1850 (Oakland, 2019), 199-215; B. Hoonhout, Borderless Empire: Dutch Guiana in the Atlantic World, 1750-1800 (Athens, Ga., 2020).

19 Miller, Slavery as History.

20 Juliane Schiel and Christian G. De Vito, eds., "Contextualizing the History of the Enslaved Modalities of Coercion and Shifting Labor and Power Relations," special issue, Journal of Global Slavery 5, 2 (2020).

${ }^{21}$ M. van Rossum, A. Geelen, B. van den Hout, and M. Tosun, Testimonies of Enslavement: Sources on Slavery from the Indian Ocean World (London, 2020).

${ }^{22}$ Benedetta Rossi, ed., Reconfiguring Slavery: West African Trajectories (Liverpool, 2009). See also Lovejoy, Transformations; and Dalrymple-Smith, Commercial Transitions. 
why specific regimes of slavery and labor coercion occurred and how these developed along different trajectories in interaction with external influences. The urgency of shifting our attention in this direction is increased by the advances made in scholarship on early modern slavery outside of the Atlantic realm. This rapidly expanding historiography indicates the existence and diverse natures of slavery and slave trade in the Mediterranean, the Islamic world, the Western Indian Ocean world, South Africa, South and Southeast Asia, and Central Asia. ${ }^{23}$ These studies also indicate that in many regions of the world formal slavery and commercial slave trading coexisted with a large variety of non-commodified and often informal forms of slavery, most importantly caste, debt, and kinship slavery. There have been important advances in expanding the scope of the global history of slavery, in increasing our understanding of the impact the slave trade had on the development of slavery, and in deconstructing the complexities of the spectrum of coerced labor. However, these advances have yet to generate a fully encompassing global-historical analytical framework that allows us to interrogate the full range of slavery regimes and their transformations and persistence.

\section{DEFINING SLAVERY - THE FORMAL AND THE INFORMAL}

Exploring the transformation of slavery through the trajectories of different regimes requires a clear delimitation of what we mean by slavery and slavery regimes. This article takes as starting point that slavery is defined only in part through legal systems and must be primarily understood as a

\footnotetext{
23 On the Mediterranean, see S. Hanss and J. Schiel, eds., Mediterranean Slavery Revisited (500-1800): Neue Perspektiven auf mediterrane Sklaverei (500-1800) (Zürich, 2014). On the Islamic world: W. G. Clarence-Smith, Islam and the Abolition of Slavery (Oxford, 2006). For the Western Indian Ocean: J. Ewald, "Crossers of the Sea: Slaves, Freedmen, and other Migrants in the Northwestern Indian Ocean, c. 1750-1914," American Historical Review 105, 1 (2000): 69-91; P. Machado, “A Forgotten Corner of the Indian Ocean: Gujarati Merchants, Portuguese India and the Mozambique Slave-Trade, c. 1730-1830," Slavery \& Abolition 24, 2 (2003): 1732; Jane Hooper and David Eltis, "The Indian Ocean in Transatlantic Slavery," Slavery \& Abolition 34, 3 (2013): 353-75; M. Hopper, Slaves of One Master: Globalization and Slavery in Arabia in the Age of Empire (New Haven, 2015); and S. Subrahmanyam, "Between Eastern Africa and Western India, 1500-1650: Slavery, Commerce, and Elite Formation," Comparative Studies in Society and History 61, 4 (2019): 805-34. For South Africa: N. Worden, Slavery in Dutch South Africa (Cambridge, 1985); and R.C.H. Shell, Children of Bondage: A Social History of the Slave Society at the Cape of Good Hope, 1652-1838 (Johannesburg, 1994). On South and Southeast Asia: S. Arasaratnam, "Slave Trade in the Indian Ocean in the Seventeenth Century," in K. S. Mathews, ed., Mariners, Merchants and Oceans: Studies in Maritime History (New Delhi, 1995), 195-208; I. Chatterjee and R. M. Eaton, eds., Slavery and South Asian History (Bloomington, 2006); and Van Rossum, Kleurrijke tragiek: De geschiedenis van slavernij in Azië onder de VOC (Verloren, 2015); Bosma, Making of a Periphery. And on Central Asia: J. Eden, Slavery and Empire in Central Asia (Cambridge, 2018); and S. Whitfield, Silk, Slaves, and Stupas Material Culture of the Silk Road (Oakland, 2018).
} 
practice. $^{24}$ The definition of slavery proposed here includes all coercive relations that involve formal or informal possession or usage right claims over people (or groups of people) that bind them to what contemporaries see as distinct, inferior social conditions with fewer or even no rights. ${ }^{25}$ This contextualized definition engages with all historic forms of slavery, bringing together "the 'great' hegemonic slaveries" with the "most varied local 'small' slaveries." "26 It also allows us to make useful distinctions between slavery and other regimes of coercion and bondage. One of these is regimes of coercion that extend to entire populations based on their subjecthood, especially corvée and labor tax regimes (though slaves could be used to perform or pay such obligations on behalf of their masters). A second type is convict labor regimes, although this distinction applies especially to societies where convicts generally retain many of their rights. The latter contrasts with societies where people lose most of their social rights, more or less permanently, and can become enslaved or slave-like through punishment.

It is important to note that this implies that different practices of slavery can coexist, interact, or conflict within the same society, ${ }^{27}$ and that such slavery practices are regulated by sets of organizing mechanisms that together make up slavery regimes. It is useful to think about regimes as "a particular way of operating or organizing a system"-or more specifically here, about slavery and bondage as sets of social asymmetrical dependent and coercive relations-because that brings into play not only the who (actors) and what (forms) of these relations, but also how these are upheldby what or by whom. This makes visible a distinction that is as simple as it is crucial, but nevertheless is too often overlooked in work on slavery. Slavery regimes can be either formal, meaning that they are regulated by polities such as local chiefdoms, states, and empires, or they can be informal, not meaning that they are unregulated but rather that they are regulated by "other" social entities, such as the community or households rather than by polities or formalized laws.

In contrast to what we may be inclined to think, historically these "classic" or "hegemonic" formal regimes of slavery, with their malleable but nevertheless laid down and enforced rules, provided a large degree of continuity in shaping slavery, especially because they were marked by a

24 J. Miller, The Problem of Slavery as History: A Global Approach (New Haven, 2012).

25 Thus, it relies partly on Patterson and Van der Linden, and more loosely, H. J. Nieboer, Slavery as an Industrial System: Ethnological Researches (The Hague, 1900); Van der Linden, "Dissecting Coerced Labour," in M. Van der Linden and M. Rodríguez García, eds., On Coerced Labour: Work and Compulsion after Chattel Slavery (Leiden, 2016), 291-322; and O. Patterson, Slavery and Social Death: A Comparative Study (Cambridge, Mass., 1982), 22.

26 Zeuske, "Research Problems," 105.

27 Suzanne Miers, "Slavery: A Question of Definition," Slavery and Abolition 24, 2 (2003): 116; Van Rossum, "Global Slavery." 
familial resemblance to " "great' slavery in a tradition of 'Roman Law.", 28 In contrast, the informal regimes of slavery seem more susceptible to change, more fluid and adaptable. Actors upholding such regimes, such as communities, villages, and households, are bound much less by legal norms of law and property and more by practices, customs, and expectations that can shift in the face of internal and external pressures.

It is important to mark this distinction because doing so allows us to develop a new logic for investigating the history of slavery. First, it warns against discarding informal, smaller forms of slaveries as irrelevant, nonstandard, "local," or "special." Second, and more important, we must consider whether what shaped the nature of slavery and bondage over time was not so much the trajectories of formal slavery regimes and their abolitions, but that it was the trajectories of the more adaptable and widespread informal slavery regimes, especially, that were key factors in its transformation. Third, this implies that we cannot attribute slavery's persistence only to transformations of slavery regimes that occurred after slave trade and legalized slavery were formally abolished. In fact, the expansion and development of the pervasive and many-sided informal forms of slavery encountered today seem, to a large extent, to have taken place during the early modern expansion of commodified legal regimes of slavery and slave trading across the globe, especially in those environments where formal slavery occurred alongside and in interaction with existing local and informal slavery regimes.

What is proposed here is that we need to explore the idea that it is slavery's versatility, its capacity to transform and adapt, that explains its persistence over time. Put another way, slavery manifested itself through different formal and informal regimes, with their own trajectories, which existed and developed alongside each other. This implies that the long-term and global transformations of slavery were shaped by these multiple trajectories of slavery regimes, which did not develop in isolation but responded to external influences and each other. This was perhaps more explicit in the Indian Ocean and Indonesian Archipelago worlds than in the Atlantic, and it is no coincidence that those two regions figure most prominently in the persistence of modern forms of slavery.

EXPLORING ALTERNATIVES: THE INDIAN OCEAN AND INDONESIAN ARCHIPELAGO WORLDS

The early modern Indian Ocean and Indonesian Archipelago worlds therefore provide a crucial arena in which to test and improve conceptualizations and understandings of the historical transformations of different forms of slavery,

${ }^{28}$ Zeuske, "Research Problems," 87. 
because these regions were marked by great diversity in the regimes of slavery, which interacted with the rapid expansion of the slave trade. ${ }^{29}$ The history of slavery we encounter here is not entirely different from that of the Atlantic world, but it is more intertwined and integrated with aspects that were, geographically, much more distanced in the Atlantic. Throughout the Indian Ocean and Indonesian Archipelago worlds, enslavement regions, slave-based production areas, consumer markets, and strong, developed states were mixed together in complex configurations. First, the connections forged by the long-distance slave trade were multidirectional, coercively circulating enslaved people on a large scale between Southeast Asia, South Asia, the Middle East, East Africa and South Africa, and Madagascar. Second, regions of enslavement and the export slave trade were not separated from slave importing regions by a single trans-oceanic crossing but could be located along the same coast; importing and exporting regions could be one and the same. South and Southeast Asian slavery regimes therefore offer a range of complex and nuanced manifestations of slavery forms that were connected, but also developed along different trajectories.

The myriad of slavery regimes and related forms of coerced labor has been a central theme for historiographies of societies in South and Southeast Asia. ${ }^{30}$ Debt slavery was common throughout the Indonesian Archipelago, but also played an important role in enslavement in South India. ${ }^{31}$ Slaves could be tied to the land in Timor $^{32}$ and on the southwest Indian Malabar coast. ${ }^{33}$ This resembled the corvée systems in, for example, Sri Lanka, Java, and the Moluccas. ${ }^{34}$ Caste could play a role in slavery and corvée relationships in Sri Lanka and the Malabar coast, while on Bali debt and legal punishment were reported to be prominent in enslavement. ${ }^{35}$ Enslavement through war

${ }^{29}$ K. Ward, "Slavery in Southeast Asia, 1420-1804," in D. Eltis et al., eds., The Cambridge World History of Slavery: Volume 3, AD 1420-AD 1804 (Cambridge, 2011), 163-85.

30 Ward, "Slavery"; Chatterjee and Easton, Slavery.

31 P. Boomgaard, "Human Capital, Slavery and Low Rates of Economic and Population Growth in Indonesia, 1600-1910," Slavery \& Abolition 24, 2 (2003): 83-96; R. B. Allen, European Slave Trading in the Indian Ocean, 1500-1850 (Athens, Oh., 2015); Van Rossum et al., Testimonies of Enslavement.

32 H. Hägerdal, Lords of the Land, Lords of the Sea: Conflict and Adaptation in Early Colonial Timor, 1600-1800 (Leiden, 2012).

33 K. Saradamoni, Emergence of a Slave Caste: Pulayas of Kerala (New Delhi, 1980); A.K.K. Ramachandran Nair, Slavery in Kerala (Delhi, 1986).

34 N. R. Dewasiri, The Adaptable Peasant: Agrarian Society in Western Sri Lanka under Dutch Rule, 1740-1800 (Leiden, 2008); J. Breman, Mobilizing Labour for the Global Coffee Market (Amsterdam 2015); G. Knaap, Kruidnagelen en christenen: De VOC en de bevolking van Ambon 1656-1696 (Leiden, 2004).

35 Chatterjee and Eaton, Slavery; H.G.C. Schulte Nordholt, The Spell of Power: A History of Balinese Politics, 1650-1940 (Leiden, 2010). 


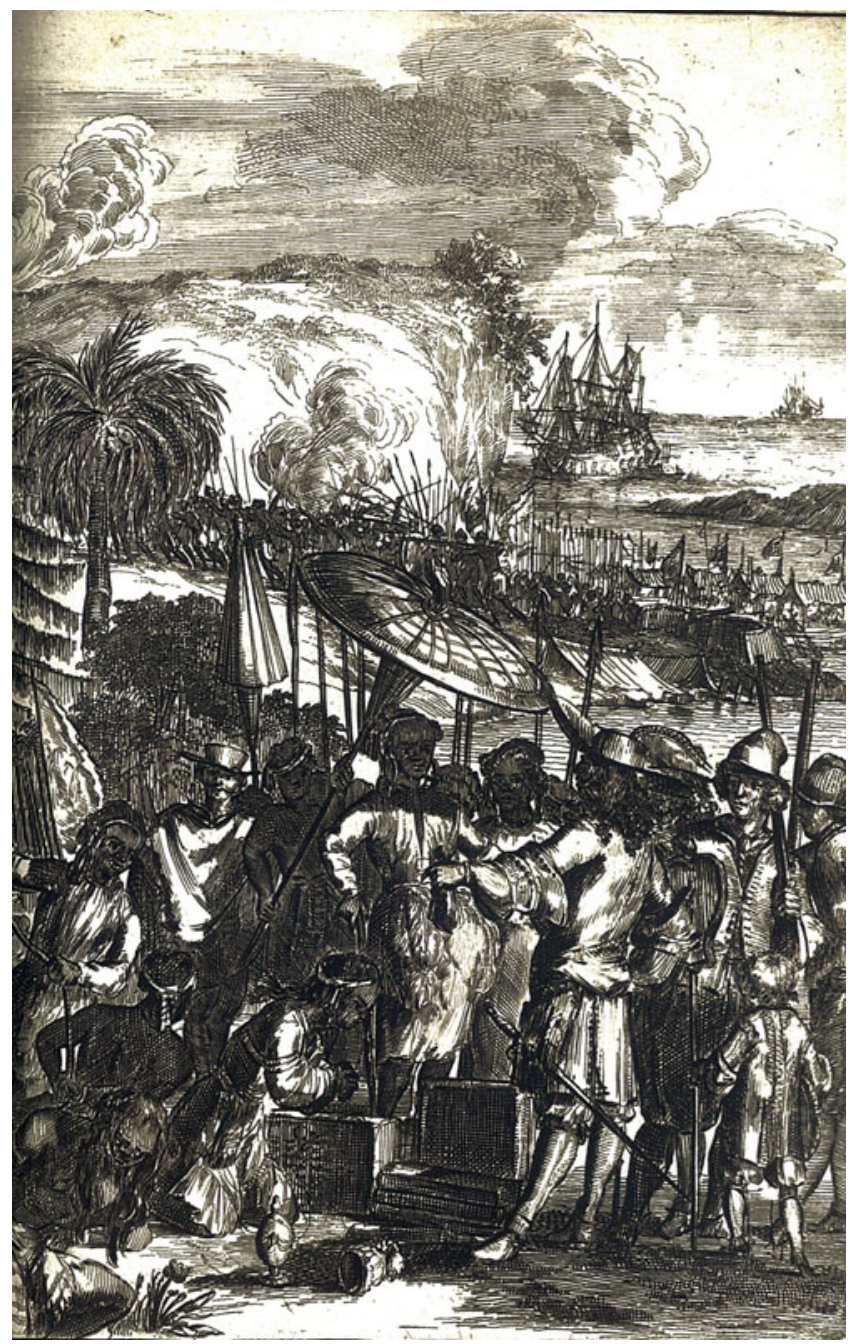

Image 1. Arakanese and Dutch slave traders in Pipli (India) in the Bay of Bengal. In Wouter Schouten, Oost-Indische Voyagie III (Amsterdam, 1676), p. 10.

played a role in Bengal, Sulawesi, Bali, Java, and elsewhere. ${ }^{36}$ Several largescale slave raiding polities existed at different times, most notably in Arakan

36 M. Vink, "'The World's Oldest Trade': Dutch Slavery and Slave Trade in the Indian Ocean," Journal of World History 14, 2 (2003): 131-77. 


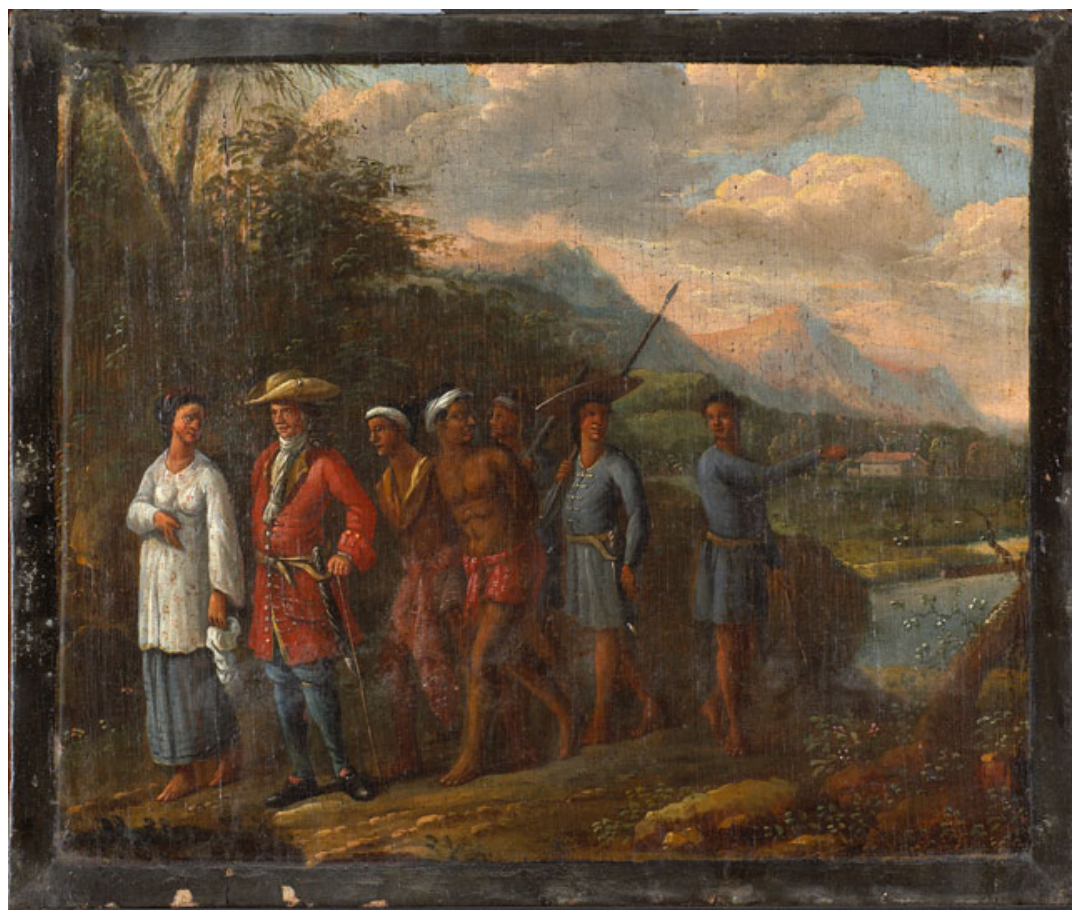

Image 2. Merchant of the Dutch East India Company with his wife, soldiers, and enslaved or captive individuals. Rijksmuseum Amsterdam, SK-A-4988-00.

and Makassar in the seventeenth century ${ }^{37}$ and, in the late eighteenth century, the Sulu Sultanate. ${ }^{38}$

Recent research has begun to uncover the concurrence of widespread commercial slavery and the expansion of slave trading in the wider Indian Ocean world in the early modern period. ${ }^{39}$ Although commercial slave trading was known to exist throughout Asia, earlier scholarship mostly disregarded it as a less important exception to the wider landscape of forms

37 S. van Galen, Arakan and Bengal: The Rise and Decline of the Mrauk U Kingdom (Burma) from the Fifteenth to the Seventeenth Century AD ( $\mathrm{PhD}$ thesis, Leiden University, 2008); J. Nagel, Der Schlüssel zu den Molukken: Makassar und die Handelsstrukturen des Malaiischen Archipels im 17. und 18. Jahrhhundert: eine exemplarische Studie (PhD thesis, Trier University, 2003).

38 J. F. Warren, The Sulu Zone: The Dynamics of External Trade, Slavery, and Ethnicity in the Transformation of a Southeast Asian Maritime State (Singapore, 1981).

39 Vink, "World's Oldest Trade"; Hooper and Eltis, "Indian Ocean"; Allen, European Slave Trading; Van Rossum, Kleurrijke tragiek; Bosma, Making of a Periphery; M. van Rossum, "Towards a Global Perspective on Early Modern Slave Trade: Prices of the Enslaved in The Indian Ocean, Indonesian Archipelago and Atlantic Worlds," Journal of Global History (forthcoming). 
of bondage that were mainly status-based and local phenomena. ${ }^{40}$ Explanatory models for slavery in Indian Ocean and Southeast Asian studies thus often focused on patterns of state formation that, especially in Southeast Asia, relied on collecting large followings by attracting and binding subjects, ${ }^{41}$ or on low population density and high labor scarcity patterns, following from the "high land to labor ratio" of the Nieboer-Domar thesis. ${ }^{42}$

Earlier research showed the importance of slavery and slave trading to the European plantation economies on the Western Indian Ocean islands, especially the French sugar plantations on the Mascarenes. ${ }^{43}$ Later studies extended that perspective to the slave trade and slave-based production in the region more widely, and included the role of Arab and Indian merchants. ${ }^{44}$ Moving away from the exclusive focus on the Western Indian Ocean, scholars have indicated the importance and spread of commercial slavery and slave trading in the wider Indian Ocean and Indonesian Archipelago regions. Portuguese merchants in the Bay of Bengal "transformed from traders to slavers" in the early seventeenth century, organizing the Bengal slave trade and "supplying slaves to faraway markets in Europe, Africa, and other parts of Asia." 45 Research into the Dutch East India Company (Verenigde Oostindische Compagnie, or VOC) archives has revealed the importance of commodified slavery in and around the VOC empire, ${ }^{46}$ supported by large flows of slaves traded from a variety of societies throughout the Indian Ocean and Indonesian Archipelago. ${ }^{47}$ The increase of commercial slavery and slave trading in early modern South and Southeast Asia has been linked to the role of slaves in peopling cities, ${ }^{48}$ the

40 Boomgaard, "Human Capital"; G. Campbell, "Slavery in the Indian Ocean World," in G. Heuman and T. Burnard, eds., The Routledge History of Slavery (New York, 2011), 52-63.

41 Reid and Brewster, Slavery, Bondage; Jennifer L. Gaynor, Intertidal History in Island Southeast Asia: Submerged Genealogy and the Legacy of Coastal Capture (Ithaca, 2016).

42 Nieboer, Slavery; E. D. Domar, "The Causes of Slavery or Serfdom: A Hypothesis," Journal of Economic History 30, 1 (1970): 18-32.

43 G.S.P. Freeman-Grenville, The French at Kilwa Island (Oxford, 1965); Edward Alpers, "The French Slave Trade in East Africa (1721-1810)," Cahier du Etudes Africaines 37 (1970): 80-124.

44 Abdul Sheriff, Slaves, Spices and Ivory in Zanzibar: Integration of an East African Commercial Empire in the World Economy, 1770-1873 (Athens, Oh., 1987); Richard Allen, Slaves, Freedman, and Indentured Laborers in Colonial Mauritius (Cambridge, 1999); Hopper, Slaves.

45 R. Mukherjee, "Portuguese Slave Ports in Bengal 1500-1700," in A. Polónia and C. Antunes, eds., Seaports in the First Global Age: Portuguese Agents, Networks and Interactions (1500-1800) (Porto, 2016), 215-36, 234.

46 Vink, "World's Oldest Trade"; Van Rossum, Kleurrijke tragiek.

${ }^{47}$ L. Mbeki and M. van Rossum, "Private Slave Trade in the Dutch Indian Ocean World: A Study into the Networks and Backgrounds of the Slavers and the Enslaved in South Asia and South Africa," Slavery \& Abolition 38, 1 (2017): 95-116.

48 Reid and Brewster, Slavery, Bondage; R. Raben, "Cities and the Slave Trade in Early-Modern Southeast Asia," in P. Boomgaard, D. Kooiman, and H. Schulte Nordholt, eds., Linking Destinies: Trade, Towns and Kin in Asian History (Leiden, 2008), 119-40. 
rise of European empires, ${ }^{49}$ and the expansion of colonial-capitalist production for global trade. ${ }^{50}$

With regard to colonial societies, this work has undermined dominant assumptions about so-called "Asian" forms of slavery, characterized as "mild" or even "cozy" urban household slavery, ${ }^{51}$ and the idea that slaves in Asia were a luxury and not a production factor, mainly serving as "objects of conspicuous consumption by elites." 52 These studies have undermined Boomgaard's argument that "if it is accepted that debt was the chief cause of enslavement, most slaves were not aliens - unless it can be proven that they were subsequently sold outside the community." 53 Slave trading did exist on a larger scale than has been previously assumed, not only in the Western Indian Ocean but also in the wider Indian Ocean and Indonesian Archipelago regions. ${ }^{54}$

This should encourage the revision of perspectives on slavery and its transformations, not only in the colonial contexts, but especially outside European colonial contexts. New research shows that throughout the Indian Ocean and Indonesian Archipelago different slavery regimes coexisted and that regions sending and receiving enslaved subjects were deeply connected. Most importantly, we have important indications that slave trade and wider forms of coerced mobility created interconnections that deeply affected the trajectories of slavery regimes in both receiving and sending societies. ${ }^{55}$

\section{MAPPING TRAJECTORIES OF SLAVERY REGIMES}

Although much more research is needed to scrutinize the dynamics of the wide variety of slavery regimes, we can already distinguish four types of regimes that are relevant to understanding the varieties of slavery regime trajectories in the Indian Ocean and Indonesian Archipelago and that help us to see links with the Atlantic and the wider global history of slavery.

49 Allen, European Slave Trading.

50 M. Mann, Sahibs, Sklaven und Soldaten: Geschichte des Menschenhandels rund um den Indischen Ozean (Darmstadt, 2012); "Labouring Transformations of Amphibious MonstersGlobalization, Diversity and the Effects of Labour Mobilization under the Dutch East India Company (1600-1800)," International Review of Social History s64 (2019): 19-42.

51 E. Jones, Wives, Slaves and Concubines: A History of the Female Underclass in Dutch Asia (DeKalb, 2010), 144.

52 Campbell, "Slavery," 61; see also Reid and Brewster, Slavery, Bondage; Boomgaard, "Human Capital."

53 Boomgaard, "Human Capital," 90.

54 Warren, Sulu Zone; A. van der Kraan, "Bali: Slavery and Slave Trade," in Reid and Brewster, Slavery, Bondage, 315-40; Vink, "World's Oldest Trade"; Raben, "Cities”; Allen, European Slave Trading; Van Rossum, Kleurrijke tragiek.

55 Ward, "Slavery"; Van Rossum, "Global Slavery." See also the example of Western India by Subrahmanyam, "Between Eastern Africa and Western India." 


\section{The Use of Conflict in Enslavement-War and Raiding Regimes}

The "gun-slave cycle" is one of the most explicit links between war, enslavement, and slave trading that can be derived from the Atlantic history of the slave trade. ${ }^{56}$ In his study of the Sulu Archipelago, Warren argues along these lines that it was the incorporation into global trading patterns in the eighteenth century's second half that stimulated slave raiding polities, and turned Jolo Island into "the most important slave center by $1800 . "{ }^{, 57} \mathrm{He}$ challenges the thesis that it was the weakening of European monopolistic trade policies that forced local polities into slave raiding and points out that "commercial and tributary activity became linked with long-distance slave raiding and incorporation of captured peoples in a system to service the procurement of trading produce., ${ }^{, 58}$ However, the late eighteenth-century transformation of the Sulu Archipelago did not stand alone. Similar links between the export slave trade and the rise of war and enslavement have been established for the Western Indian Ocean ${ }^{59}$ and other parts of South and Southeast Asia in earlier centuries. ${ }^{60}$ One can draw direct parallels to developments in parts of West Africa, for example in the Bight of Benin, where states such as the Kingdom of Dahomey used proceeds from slave raiding and the sale of captives to acquire goods which, in turn, were used to strengthen the polities' power. ${ }^{61}$

Different types of polities became involved with large-scale enslavement, varying from maritime states focused on raiding for slave exports to states involved "in the transplantation of huge population groups onto statecontrolled rice plantations." $"$ "T2 The development of the Arakan Kingdom of Mrauk U in Southeast Bengal in the seventeenth century, for instance, was based strongly on its expansion of maritime slave-raiding activities and export slave trade. ${ }^{63}$ Around the same time, the merchant polity of Makassar

\footnotetext{
56 Warren C. Whatley, "The Gun-Slave Hypothesis and the 18th Century British Slave Trade," Explorations in Economic History 67 (2018): 80-104.

57 James F. Warren, "Slave Markets and Exchange in the Malay World: The Sulu Sultanate, 1770-1878," Journal of Southeast Asian Studies 8, 2 (1977): 162-75, 162.

58 Ibid.

59 J. Hooper, "Pirates and Kings: Power on the Shores of Early Modern Madagascar and the Indian Ocean," Journal of World History 22, 2 (2011): 215-42; R. Thiebaut, Traite des esclaves et commerce néerlandais et français à Madagascar (XVIIè et XVIIIè siècles) (PhD thesis, Paris 1 and Vrije Universiteit, 2017).

${ }^{60}$ Joseph Baumgartner, "Notes on Piracy and Slaving in Philippine History," Philippine Quarterly of Culture and Society 5, 4 (1977): 270-72; Nagel, Der Schlüssel zu den Molukken; van Galen, Arakan.

${ }^{61}$ Angus Dalrymple-Smith and Matthias van Rossum, "Capitalism, Slavery and Labour Coercion in Early Modern Asia and Africa," Comparativ: Zeitschrift für Globalgeschichte und Vergleichende Gesellschatsforschung (forthcoming); Dalrymple-Smith, Commercial Transitions.

${ }^{62}$ Reid, "Slavery so Gentle."

${ }^{63}$ Van Galen, Arakan.
} 
in politically fragmented South Sulawesi was an essential link in Southeast Asia's trading system and regional slave trade. After the conquest of the city of Makassar by the VOC, small-scale warfare and enslavement continued to provide large-scale slave exports. ${ }^{64}$ The mainland Southeast Asian Kingdom of Ayutthaya was marked by warfare, slave capture, and large-scale resettlement, but also by the development of a corvée system imposed on populations within the polity. ${ }^{65}$ How the impact of enslavement by war and slave raiding impacted the regimes of coercion and slavery within these respective polities, as well as in their surrounding targeted societies, should be studied and compared much more closely to understand the effects of slave raiding and war in relation to the slave trade.

European colonial expansion undeniably had an important impact in the Indian Ocean and Indonesian Archipelago world, not unlike the Atlantic world. The Dutch East India Company, for example, used not only glass beads but also guns and gunpowder for its slave trade in Madagascar and parts of the Indonesian archipelago. In many instances, European early modern colonial powers even acted as overlords, influencing and regulating local dynamics of war, enslavement, and slave trade. The new ruler of Buton, for example, felt it important to send an envoy to the VOC Governor General Willem van Outhoorn in January 1701 to ask his permission to export slaves to Batavia. His petition does not make explicit where these enslaved would come from, but it does hold a clue: it asks for the VOC's consent to wage war against the local rival polity of Tambako in retaliation for their having recently "attacked and conquered" several villages "and robbed all the people from there." 66

\section{The Shaping of Enslavebility-Local Bondage Regimes}

War and slave raiding may have been the most visible forms of enslavement, but they were far from the only routes to slavery. In several regions we see distinct patterns of slavery and enslavement in relation to local socioeconomic relations of dependency grounded in oppressive differentiations. These patterns of enslavement linked to local dependencies seem to have been particularly common in the more developed market societies existing throughout South and Southeast Asia. In "idealized" form these dependencies were intended to keep bonded subjects within a society

\footnotetext{
64 Reid and Webster, Slavery, Bondage; Heather Sutherland, "The Makassar Malays: Adaptation and Identity, c. 1660-1790," Journal of Southeast Asian Studies 32, 3 (2001): 397-421; “Chasing the Delfland: Slave Revolts, Enslavement, and (Private) VOC Networks in Early Modern Asia," P. Brandon et al., eds., Navigating History: Economy, Society, Science and Nature. Essays in Honor of Prof. Dr. C. A. Davids (Leiden, 2018), 201-27.

65 B. Beemer, The Creole City in Mainland Southeast Asia: Slave Gathering Warfare and Cultural Exchange in Burma, Thailand and Manipur, 18th-19th c. (Honolulu, 2013).

66 NA, VOC, inv.nr. 1647, Makassar I, f. 1-4 (scan 446).
} 
-we might call these immobilizing forms of bondage based on, for example, debt, caste, and land-bound slavery. In practice, however, this norm to keep bonded subjects within a society was continually transgressed. ${ }^{67}$ Here again, it is worthwhile to explore interesting parallels with regional developments in West Africa, for example in the shifting use of coerced labor in the Asante Kingdom in response to external demands of slave trade. ${ }^{68}$

The areas of southeast India (Coromandel) and southwest India (Malabar) were important slave-exporting regions, but their patterns of enslavement and slave trading seem to have been subjected to somewhat different dynamics. Poverty has traditionally been indicated as the main mode of enslavement in the Coromandel Coast, leading to practices of self- and child-selling during times of crisis. ${ }^{69}$ At the Malabar coast, there are indications that, alongside local systems of land-based slavery, enslavement and widened transferability for the export slave trade may have been related to the adaption of local customs of caste, social expulsion, and local conflicts. ${ }^{70}$ In Java, too, debt slavery and kidnapping were also reported to be widespread, even after the expanding VOC prohibited both the enslavement and pawning (pandelingenschap) of Javanese populations. Forms of bondage existed here next to systems of corvée and commercial slavery. ${ }^{71}$ For this cluster of slavery regimes, it would be interesting to employ detailed comparison to uncover how the dynamics of internal enslavement patterns related to the impact of slave trading and trafficking networks and the export of locally enslaved or bonded people.

The issue of enslavebility — or as literally formulated in original references in Dutch sources, slaafbaarheijd — was most urgent for these societies with regimes based on largely internal processes of enslavement, perhaps even more than it was for those largely raiding or importing "aliens." The story of the fourteen-year-old slave girl Cali from Chettuva (Kerala, southwest India) is telling in this respect. Before the Dutch Court of Justice in nearby Cochin (Kochi) she testified on 22 June 1743 that she had served "since childhood" in the house of Toepas Joan Dias within the Company's boundaries (liemiet), but that she was "subject and

\footnotetext{
${ }^{67}$ The distinction between mobilizing and immobilizing forms of slavery is made in Van Rossum, "Global Slavery."

68 Dalrymple-Smith, Commercial Transitions.

${ }^{69}$ M. Vink, Encounters on the Opposite Coast: The Dutch East India Company and the Nayaka State of Madurai in the Seventeenth Century (Leiden, 2015), 288; E. Gobel, The Danish Slave Trade and Its Abolition (Leiden, 2016), 57.

${ }^{70}$ A. Geelen, "Defining Slavery in Cochin, Social Backgrounds, Tradition and Law in the Making of Slaafbaarheid in Eighteenth-Century Dutch Cochin" (Research Master Thesis, Leiden University, 2017); Van Rossum et al., Testimonies of Enslavement.

${ }^{71}$ Reid and Webster, Slavery, Bondage; Jones, Wives; Van Rossum, Kleurrijke tragiek; Breman, Mobilizing.
} 
belonging to the landlord of Chettua Paijencherij Naijro."72 She was categorized as being of the Bettua caste, which was considered a low status group of "praedial" or land-bound slaves belonging to the owner of the land. ${ }^{73}$ Notwithstanding the restrictions implied by her land-bound slave status, Cali worked outside the territories of the polity of the Chettuva landlord, and foresaw the danger of being sold and exported. She testified before the court that she fled the house of Dias, because she had learned "that the commander of the fort, the lieutenant Jan Doorn, had sent for her, to apprehend her, and then buy her from her lijfheer (master) the Paijencherij Naijro." ${ }^{, 74}$ Despite her land-bound status, the threat of being sold must have been serious to Cali. Various court cases from the Court of Justice of Cochin indicate that masters would threaten their male and female slaves of both local and non-local origins that they would "sell her on board" or "sell him to the scheepsvrienden (shipmates)." Slaves were frightened by the specter of losing all known social connections and entering an unknown world. In their testimonies before court, enslaved often referred to these threats as the reason for intense "sadness" and "bitter crying," and also escape attempts. ${ }^{75}$

Navigating in a complex, multi-sovereignty landscape, the VOC interfered with the regulation not only of who could be alienated and exported from the Malabar coast as a slave, for example through the private trade of the officers on VOC ships or via slave trade conducted by European, Indian, and Arab merchants along the coast, but also of who could actually be enslaved. Court cases on illegal abduction, deception, kidnapping, and other forms of enslavement testify to the expanding influence of colonial powers. ${ }^{76}$ Vernacular sources are available that might provide key evidence to validate, test, and expand on the insights we can gain from deep readings of the colonial archive.

The colonial archival references to a blunt term like enslavebility (slaafbaarheijd) in regions such as Dutch Cochin or the wider Malabar coast highlight hard questions behind the local and imperial reshaping of slavery

72 NA, Nederlandse bezittingen in India: Digitale Duplicaten van Archieven aanwezig in de Tamil Nadu Archives te Chennai, archive number 1.11.06.11 [hereafter NA, Chennai], inv.nr. 360, f. 283-84 (scans 175-76). For a more elaborate analysis of this case: Matthias van Rossum, "Enslavebility, Slavery and Global Micro Histories: Reflections through the Case of Cali," in H. Hägerdall, ed., Slavery in the Indian Ocean World (Athens, Oh., forthcoming). The Dutch source text of this court case is translated in Van Rossum et al., Testimonies of Enslavement.

73 E.g., Krishnat P. Padmanabha Menon, History of Kerala: A History of Kerala Written in the Form of Notes on Visscher's Letters from Malabar, vol. 2 (New Delhi, 1983), 272. For a wonderful treatise on caste and slavery in early modern Malabar, see Geelen, "Defining Slavery."

74 NA, Chennai, inv. 360, f. 285 (scan 176).

75 See, for example, the cases of Maria and Cruz in Alexander Geelen, Bram van den Hout, Merve Tosun, Mike de Windt, and Matthias van Rossum, "On the Run: Runaway Slaves and Their Social Networks in Eighteenth Century Cochin," Journal of Social History 54, 1 (2020): 66-87.

${ }^{76}$ Van Rossum et al., Testimonies of Enslavement. 


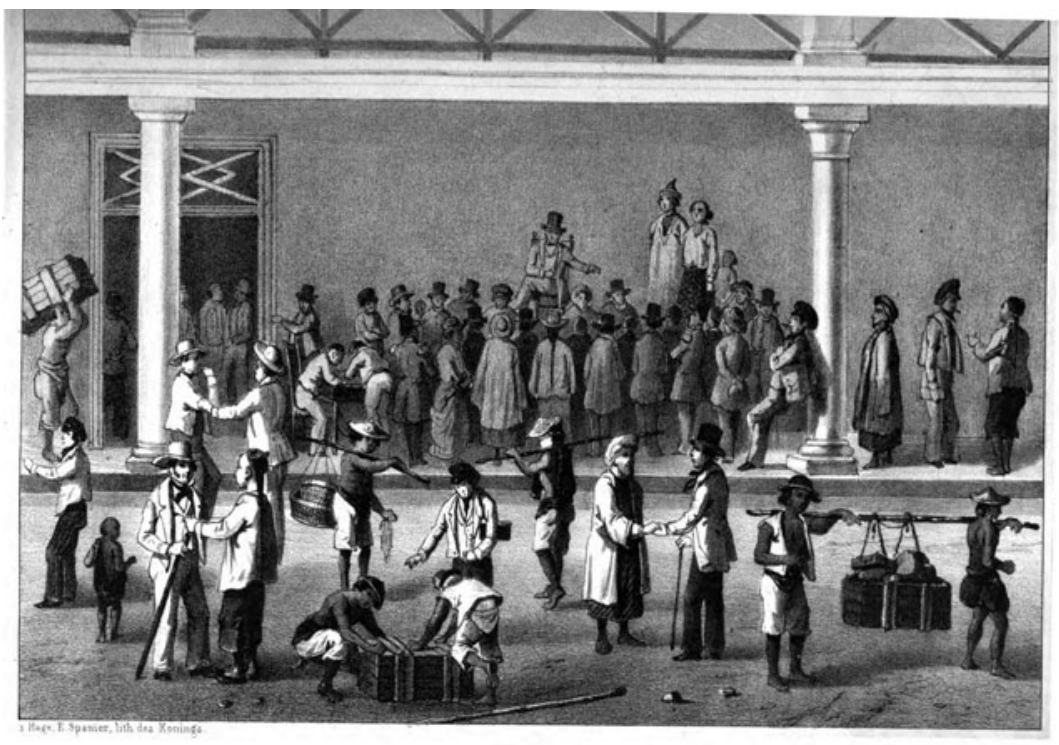

ImAGE 3. A slave sale in nineteenth-century Batavia (Jakarta). In Wolfer Robert van Hoëvell, Tijdschrift voor Nederlandsch Indië (Batavia, 1853).

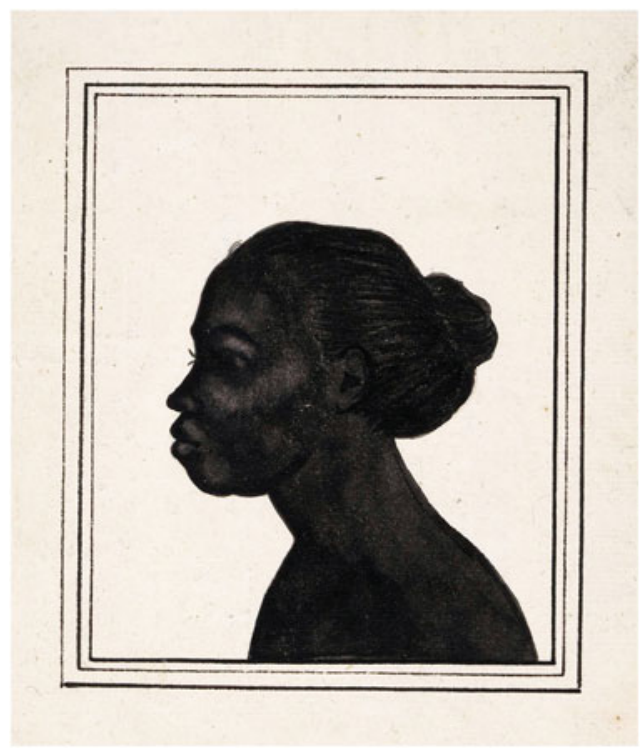

IMAGE 4. Portrait of Flora, enslaved woman in the household of VOC-servant Jan Brandes in Batavia, ca. 1780. Rijksmuseum Amsterdam, NG-1985-7-3-13. 
in societies that faced the impact of slave trade: who could be enslaved, through which means, by whom, under what conditions, and in order to make them do what? Similarly, who could be turned away from a society-sold or otherwise exported - and under what conditions? Thus, enhancing our understanding of local forms of enslavement, alienability, and the impact of the slave trade can help us better grasp the impacts these "internal inequality"-based slavery regimes had on social relations. The nineteenth-century abolitions of slave trade and slavery seem to have pushed these relations between slavery and oppressive differentiations (caste, ethnic, or racial) into the informal sphere, rather than unraveling or diminishing them.

\section{The Shaping of Alienability-Slave-Export Regimes}

Various regions developed systems in which slaves were exported on a massive scale from local slavery regimes. Whereas traders from Jolo and Macassar mainly sold "others" as slaves, most exports from these regions involved bonded or enslaved people taken directly and openly from those societies themselves. Nai or Wange Hendrik Richard van Bali described this in his unique memoires. He was the son of a free man and an enslaved mother in a village on Flores and born in the late 1790s. After his mother died he was sold to slave traders in Sumbawa (and later Java) by "the Lord and the Master."77 The existence of bondage, slavery, and slave trading in the Indonesian archipelago in the early modern period has been widely acknowledged, yet their interrelations have not been examined extensively, most studies having focused on local aspects of such bondage systems. ${ }^{78}$ Some have touched on slavery, trade, and raiding in important centers of slave trading such as Jolo, Macassarm, and Bali, ${ }^{79}$ but little attention has been paid to how local slavery regimes were transformed into large-scale export systems. The difference with the patterns of war and slave-raiding is important: in contrast to slave-export polities that sold mostly "outsiders," people exported from Bali, Nias, and the Lesser Sunda Islands were mainly their inhabitants. The slave trade from these regions developed into largescale export trades. For example, some 100,000 to 150,000 enslaved people are estimated to have been exported from Bali in the seventeenth and eighteenth centuries.

77 Titas Chakraborty and Matthias van Rossum, "Slave Trade and Slavery in Asia-New Perspectives," Journal of Social History 54, 1 (2020): 1-14; based on the memoires of Wange Hendrik Richard van Bali, "De Herinnering van Levens Loopen van Na1^ op het Dorp Leeot op het Eiland Magarij na bij Bima, bij het Eiland Java, nu Wange Heindrik Richard van Balie."

78 J. L. Watson, ed., Asian and African Systems of Slavery (Berkeley, 1980); Reid and Webster, Slavery, Bondage.

79 Warren, Sulu Zone; H. Sutherland, "Slavery and the Slave Trade in South Sulawesi, 1660s1800s," in A. Reid with J. Brewster, eds., Slavery, Bondage, and Dependency in Southeast Asia (St. Lucia, 1983); Van der Kraan, "Bali"; Schulte Nordholt, Spell of Power. 
It has been noted that this slave trade significantly impacted the trajectories of such regimes. Bali was one of the Hindu societies of Southeast Asia, and it has been argued that slave trading strengthened existing societal hierarchies there since it "led the common people to seek the protection of a strong ruler, in spite of the fact that these were the major slave traders. ${ }^{.80}$ Before the seventeenth century, Nias was characterized "by a closed system wherein slaves were not alienable within the society, ${ }^{\prime} 81$ but under the pressure of the slave trade spreading throughout the Indonesian Archipelago slaves became an important export commodity. Especially Acehnese and European slave traders and raiders increasingly drew people from Nias, which was characterized by tribal cultures.

Sources on the slave trade written by European merchants can throw light on these dynamics. An April 1688 Dutch report from the VOC ship Goudvis, for instance, narrates how the human expulsion from Nias was a trickling trade, as local kings and villagers came to the beach to sell just one, two, or three people at a time. Often these were young men or women, or people that were ill, or perhaps convicted of a crime. Within a few days, the Dutch merchants refused one male slave because he had "a large swelling above the chin (being infected)" and was "too expensive." ${ }^{\text {" }}$ Others were considered too "young and small for the Company" and the sellers were told that the Company "did not desire such young slaves, but some strong boys of twenty to twenty-five years old." The sellers replied that "now they know that the Company desires large slaves, they would go forth to get slaves of such age and strength as were said." ${ }^{83}$ The role of local orankaijs (rulers) and villagers seems to indicate the enslaved were locals, exported based on forms of social expulsion that may have been expanded under the pressure of the demands of external slave trade. In some areas, local rulers claimed a role in regulating and profiting from this. The ship's interpreter, for example, "warned that it was a custom here, that one had to present gifts to the regents before they would grant their inhabitants permission to come with slaves, and without their consent no one was allowed to come to the beach with us. ${ }^{" 84}$ Much more research is needed on these often underdocumented societies; in many cases few local sources have been preserved, but colonial archives can play an important role. Key questions surround the dynamic interplay between local slavery, networks of commercial slave trading, and regimes that allowed a large-scale slave export trade to develop. Answering these questions will help explain local bondage and slavery export regimes and how they were transformed.

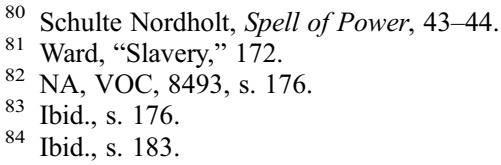




\section{The Use of Enslaved Labor-Slave Import Regimes}

It is clear that throughout the Indian Ocean and Indonesian Archipelago slavery regimes existed and developed that depended primarily on import slave trade, with the enslaved being imported mostly from or via societies marked by the abovementioned categories of slavery regimes. This does not mean that those regimes were exclusively exporting slaves, because those societies also had slavery and import slave trades. In contrast, the marked characteristic of these import regime societies was their strong dependence on slave trade to sustain enslaved populations. Slavery in these import societies was primarily commodified slavery-slaves were bought and sold for the purposes of economic production, household labor, or to acquire social status. In Southeast Asia and South Asia, this could result in slave-based societies in which onethird or more of the population consisted of enslaved persons. For the colonial societies there, these are often seen as urban regimes: from Cape Town to Hugli and Calcutta, and from Malacca to Batavia. ${ }^{85}$ Yet, in most cases, these extended into or were directly connected to rural environments that were geared toward slave-based agricultural production, such as the ommelanden of Batavia and the hinterland of the Cape. Outside the Atlantic, too, the wide variety of slave import regimes included places created around mining (e.g., in Sumatra and Java) or plantation production (e.g., Mascarenes and the Banda Islands) ${ }^{86}$ This invites an exploration of the parallels here with slavery regimes in the Atlantic, such as in Brazil, the Guyanas, the Caribbean, and North America.

\section{A GLOBAL COMPARATIVE APPROACH TO TRAJECTORIES OF SLAVERY REGIMES}

All this needs to be developed further by more source and comparative work. What, then, are the challenges for a global approach to slavery? First, our understandings and categorizations must be refined and rearranged by systematically scrutinizing historical case studies. Second, we must develop a deeper understanding of the everyday functioning of these regimes. The goal here is not to develop comparisons based on ahistorical abstractions, but to organize historical comparisons in a systematic new and open manner in order to reconceptualize things from the ground up. This inductive approach will allow us to advance the field of global slavery studies through historically localized and contextual knowledge, based on and tested by

\footnotetext{
${ }^{85}$ For example, see literature on Cape Town, but also the excellent work of Titas Chakraborty, "The Household Workers of the East India Company Ports of Pre-Colonial Bengal," International Review of Social History 64 (2019): 71-93; H. Niemeijer, Batavia: de samenleving van Batavia in de 17de eeuw (Amsterdam, 2005).

${ }^{86}$ Van Rossum, Kleurrijke tragiek; M. van Rossum, "The Dutch East India Company and Slave Trade in the Indian Ocean and Indonesian Archipelago Worlds, 1602-1795," Oxford Research Encyclopedia of Asian History (Feb. 2020).
} 
micro-historical explorations of everyday perspectives. Third, none of these local slavery regimes were isolated or self-contained; despite their differences, all related in distinct ways to external connections, perhaps most notably the slave trade. The differential impacts the trade had on local societies and their slavery regimes help explain their different trajectories.

So, we need to understand the history of the development slavery to be the interplay of all of the historical trajectories of these different, but coexisting and entangled local regimes. We therefore face the daunting task of tracing that history through a wide, comparative base of thick-description historical case studies of slavery regimes across the globe, from the Indian Ocean and Indonesian Archipelago to the Atlantic, from East Asia to Europe. Only then will we begin to understand (1) the differential impacts the slave trade had on local regimes; (2) the relations different slavery regimes had with other, nonslavery forms of coercive relations such as contract labor and corvée labor; and (3) the complex ways in which these interacted and influenced each other through competition, replacement, or transformation into new forms.

These questions are especially important to understanding slavery's afterlife and persistence. With the formal abolitions of the slave trade, and later slavery itself, labor coercion became increasingly channeled through various "other" forms of coercion, from corvée regimes organized by colonial states to coercive coolie contract labor regimes. Slavery itself did not completely disappear, but rather became increasingly less formalized, manifesting as "bondage" or what we now recognize as "modern slavery." Throughout South and Southeast Asia, as well as in former European colonies, these transformations seem to have been masked by local variations of nineteenth-century, often colonial notions that local slaveries were "traditional," "indigenous," and more "benign," conceptualizations that still haunt our understandings of slavery outside the Atlantic. They survive via not only older academic discourses but also public debate in oncecolonizing countries in Europe as well as in places like Thailand, India, and Indonesia. ${ }^{87}$ For this reason, revisiting the nature and trajectories of slavery in different parts of the world is not just important to global academic debates; it carries contemporary local and social urgency as well.

${ }^{87}$ On Thailand, see O. Tappe, "Variants of Bonded Labour in Precolonial and Colonial Southeast Asia," in S. Damir-Geilsdorf et al., eds., Bonded Labour: Global and Comparative Perspectives (18th-21st Century) (Bielefeld, 2016). On India: Ramachandran Nair, Slavery; Miers, "Slavery: A Question of Definition"; Indrani Chatterjee, "Abolition by Denial: The South Asian Example," in Gwyn Campbell, ed., Abolition and Its Aftermath in Indian Ocean Africa and Asia (London, 2004), 150-68. On Indonesia: N. Peters, Depok Slaves: The Dream of Cornelis Chastelein (Volendam, 2019). 
TOWARDS A GLOBAL COMPARATIVE AND CONNECTING MODEL

How then to proceed, if we want to better grasp how specific formal and informal slavery regimes developed across the globe, both within and outside the Atlantic, and how their multiple trajectories influenced long-term global transformations of slavery? This article contends that a breakthrough in the understanding of slavery and its persistence will require a collaborative effort, based on an approach that is both comparative and connecting, informed by new sourcebased studies of a broad range of cases. Developing such an inductive, connecting, and comparative global-historical approach will rely on the wealth of information that can be generated through in-depth studies of different coercive labor regimes and their dynamics, developments, and interactions. This requires that we formulate and apply a more explicit framework of interrogation to guide thick descriptions of the multitude of historical cases by providing thematic intersections through which to compare them.

The remainder of this article provides an initial contribution toward building such a framework. My intent is not to create a top-down, universalizing mold, but rather to enable a systematic and comparative analysis of how local slavery regimes developed. Building upon existing frameworks that address different aspects of slavery and its adaptable nature (table 1), our analytical model must allow for the integration of different elements of slavery regimes while it considers the role of internal and external mobility, the interactions between different regimes (connections), and their political-economic contexts (external influences). Taking together the dynamics of these regimes, their connections, and external influences (table 2), we can begin to better understand the trajectories of slavery regimes and their impacts in world history.

Despite the vast and expanding body of research into slavery and other forms of labor coercion, its historiography is still marked by "wide disagreement about the concepts needed to analyze coerced labour." ${ }^{, 88}$ The reason for this is slavery's adaptable nature. One traditional solution to this has been to confine the definition and study of slavery to a "property" relationship, where slaves are a commodity or a means of production. Although slavery has been defined in legal terms of ownership in different cultures, from Roman to Islamic, legal practices of property claims and rights are historically manifested in diverse ways and are not always clearcut. They consist of a range of elements concerning the rights and duties of ownership, including the right to partially, fully, or exclusively possess, use, manage, exploit, punish, and transfer. ${ }^{89}$

${ }^{88}$ M. van der Linden, "Dissecting Coerced Labour," in M. Van der Linden and M. Rodríguez García, eds., On Coerced Labour: Work and Compulsion after Chattel Slavery (Leiden, 2016), 291-322, 291.

89 Patterson, Slavery and Social Death; Clarence-Smith, Islam; Van der Linden, "Dissecting." 
TABLE 1.

Existing Perspectives on Slavery and Their Aspects

\begin{tabular}{|c|c|c|}
\hline $\begin{array}{l}\text { Momentary } \\
\text { Perspective }\end{array}$ & Regimes Perspective & Connections Perspective \\
\hline Entry & Origins and entry & $\begin{array}{l}\text { Direction of transfer } \\
\text { (import) }\end{array}$ \\
\hline Relationship & $\begin{array}{l}\text { Methods of } \\
\text { bindingFunctionAssimilability }\end{array}$ & $\begin{array}{l}\text { Type of transferPatterns of } \\
\text { coerced mobility }\end{array}$ \\
\hline Exit & $\begin{array}{l}\text { Alienability or transferabilityLegal or } \\
\text { illegal exit }\end{array}$ & $\begin{array}{l}\text { Direction of transfer } \\
\quad \text { (export) }\end{array}$ \\
\hline
\end{tabular}

TABLE 2.

Integrated Framework for Analyzing Slavery Regime Trajectories

Slavery Regime Element Aspect

\begin{tabular}{ll}
\hline Regimes & (i) origins and entry $^{1}$ \\
& (ii) methods of binding \\
& (iii) the function of the labor regime or relationship \\
& \\
& (iv) the regulation of assimilability \\
& (v) the regulation of alienability or transferability \\
& (vi) the opportunities for legal or illegal exit \\
Connections & (vii) paths (types of entry and exit) \\
External Influences & (viii) transfers and flows (types, directions, and patterns) \\
& (ix) international political developments \\
& (x) economic and environmental developments
\end{tabular}

${ }^{1}$ Key questions here are: What are the origins into specific regimes of bondage and enslavement? (a) What are the criteria for bondage or enslavebility? Under what conditions are people (allowed to) be bonded or enslaved? (b) What are the real, existing practices? (c) Local or non-local origin? Were people bonded before? (d) Type of entry into host society: How did people find their way into dependency - hereditary, tribute, impoverishment, sale, punishment, abduction, war, or slave raid (hereditary, commodified, political, criminal, war)?

${ }^{2}$ Key questions: What is the method of binding. Through what mechanism or feature are the subjected tied to a master or ruler, or enslaved persons bound to a master, and on what basis (legal property, land, debt, caste, status)?

${ }^{3}$ Key questions: What is the function or object of coercion, and the coerced labor relation? Is it social reproduction, subsistence, public (non-market production), or market-oriented (private or state)?

${ }^{4}$ Key questions: How is the relation organized in terms of social mobility and integration into the host society? Are there specific regulations regarding assimilability and social mobility? What is the discourse or ideology, and what are the practices?

${ }^{5}$ Key questions: How is the relation organized in terms of transferability? Is there formalization and regulation of (i.e., restriction of) transferability of subjected or bonded people? (a) What are the criteria for transferability? Under what conditions can people be transferred, and on what basis? (b) What are the real, existing practices? (c) Does this involve commodified transfers (i.e., are people sold?), or other kinds of transfer, such as tribute?

${ }^{6}$ Key questions: What are the exits from specific regimes of bondage and enslavement? (a) Within the regime: are there exits from bondage or enslavement, such as emancipation, buying freedom, upward social mobility, or escape, and what are the routes? Are they legal or illegal? (b) Outside the regime: are there exits from society, into other regimes of bondage or enslavement (this relates to aspect v), or otherwise? Are they legal or illegal? 
Even when slavery is restricted to property relations, it is clearly insufficient to reduce slavery to mere taxonomies of different relationships. Understanding it requires research into the manifestations of slavery regimes with their oftenmultiple claims and positions, assigned roles, norms, and regulations. Conventionally, a distinction has been made between "open" and "closed" systems, ${ }^{90}$ where the former are based on social ties, providing opportunities for slaves to become part of the kinship structures of slave owners. In such systems, the enslaved are "outsiders who are in the process of being incorporated as kinsmen" (assimilability). By contrast, closed systems of hereditary slavery are rooted in institutionalized possession relationships that ensure the enslaved "remain outside the dominant kinship system," turning them into permanent outsiders. ${ }^{91}$ This distinction is important, but has recently been criticized because the concepts of "closed" and "open" are used in two potentially conflicting ways, referring not only to social exclusion or inclusion in slave-owning social (or kin) structures, but also to the (in)alienability of slaves. ${ }^{92}$

Scholars of African and Asian slavery have recently advanced the slavery debate with the insight that it is crucial to consider that systems of bondage and slavery are not only about the possession of people, but more generally about the availability of people - or in essence, their bodies - for different possible purposes (obligated labor, social status, kinship, etc.). ${ }^{93}$ Zeuske thus speaks of "slaveries" in the plural, emphasizing the different and changing manifestations of slavery that he defines, not by alienability, but by the core element of the partial or complete availability (Verfügbarkeit) of people's bodies. ${ }^{94}$ The notion of availability, in turn, has inspired the development of a framework built around the function (or object) of the different coercive labor regimes of bondage, corvée, and slavery. Elsewhere I have argued that there is a distinction between the ways in which coercive regimes organized this availability of coerced labor, by either mobilizing or localizing people. ${ }^{95}$ In this distinction, the key commonality of the many and pluriform localizing or immobilizing regimes was that they were oriented toward maintaining local orders of obligations and "unfreedom." They were intended to keep bonded subjects inside these social or political orders, tying down people socially and spatially to their community, polity, ruler, or land (as in caste, land and debt slavery, corvée, or serfdom). This contrasts with mobilizing regimes - such as commodified or market slavery, but often also

\footnotetext{
90 Watson, Asian and African Systems; Reid and Webster, Slavery, Bondage; Reid, "Slavery so Gentle"; Ward, "Slavery."

91 Watson, Asian and African Systems, 6.

92 E.g., Reid and Webster, Slavery, Bondage; Ward, "Slavery;" see also Van Rossum, "Global Slavery."

93 Miller, Slavery as History; Zeuske, "Research Problems."

94 Zeuske, "Research Problems," 11.

95 Van Rossum, "Global Slavery."
} 
war slavery and captive slavery - in which the coercion and control of people was based on their movement across community boundaries, on their mobilizing effect. ${ }^{96}$

A framework guiding thick descriptions of coercive labor regimes should not focus on one or the other of these viewpoints (table 1) but should employ and combine the different elements underlying these different perspectives (table 2). The elements of existing comparative frameworks are not mutually exclusivethey overlap and interrelate. We can identify and integrate the key elements that correspond across these approaches. The "moments" of coercion-entry, work/ relationship, and exit - directly relate to pivotal elements of the open-closed dichotomy, namely the alienability of the enslaved (entry and exit) and the assimilability of the enslaved (during the relationship). The perspective of the (im)mobilizing function of regimes, in turn, focuses on the work/relationship moment, as well as the methods of binding and of organizing entry and exit. This is important to note, because it lets us overcome the scattered usage of the different existing perspectives, which illuminate different aspects of the same phenomena. In short, an inductive comparative agenda needs to bring together the key elements within a single, renewed, and open framework of inquiry that allows for thick descriptions of slavery regime case studies. The research framework provided does so by inviting the description of practices and regulations of regimes of slavery, as they are shaped by: (i) the origins and entry of the enslaved; (ii) the methods of binding the enslaved; (iii) the function of the labor relation or regime; (iv) the regulation of assimilability; (v) the regulation of alienability or transferability; and (vi) the opportunities for legal or illegal exit.

This framework of interrogation should be used, not for merely static or contrasting comparisons of supposedly different local variations, but rather as a tool for analyzing regime trajectories over time through integrative comparative analyses. $^{97}$ The slavery regimes of interest were not selfcontained phenomena but were transformed in interactions with each other and other external influences. This means the exchange of slaves between societies was crucial in shaping local regimes, in both receiving and sending societies. Slaves moved between societies, though not always in the same way. The analytical framework therefore should not only compare, but also address connections through the paths that channeled the internal and external mobility of enslaved people, as well as the direction of the coerced mobility (sending,

\footnotetext{
96 This is elaborated in Van Rossum, "Global Slavery." On the immobilizing effects of corvée regimes, see Matthias van Rossum and Merve Tosun, "Corvée Capitalism: The Dutch East India Company, Labour Regimes and (Merchant) Capitalism in Early Modern Asia," Journal of Asian Studies (forthcoming).

97 M. van der Linden, Het naderende einde van de vaderlandse geschiedenis en de toekomstige studie der sociale bewegingen (Inaugural Lecture, University of Amsterdam, 1999).
} 
receiving, or both) and the type of transfer, either commodified (slave trade) or non-commodified (e.g., tribute, war, or deportation).

The connections between regimes of slavery and, most visibly, the external slave trade, influenced not only the spread of commodified and other slavery regimes, but also the wider set of internal and external political, economic, and social factors that shaped the trajectories and characters of those regimes. ${ }^{98}$ The slave trade could, for example, lead to shifting restrictions on the transferability of enslaved subjects, as it did in Nias, ${ }^{99}$ and the methods of controlling and binding enslaved subjects, as in Malabar, ${ }^{100}$ but also to increasing enslavement through poverty, as in Coromandel, ${ }^{101}$ or enslavement as legal punishment, as in Bali. ${ }^{102}$ The impact such slave exports had on the commodification of local regimes has been extensively explored for West Africa and for the Western Indian Ocean. ${ }^{103}$ With regard to South and Southeast Asia and elsewhere, we know fairly little about the extent of slave trading or other forms of coerced transfer or mobility, or their impact on local slavery regimes. ${ }^{104}$

\section{PRACTICAL WAYS FORWARD-ON METHODS AND SOURCES}

This article has called for an inductive comparative approach that incorporates and analyzes source-based observations of a multitude of case studies of slavery regimes, in relation to reconstructions and analyses of the connections or interactions forged through regional patterns of coerced mobility. The goal is to analyze different trajectories and their place within the long-term, diverse, and global development of slavery. What are the practical implications of this endeavor, and what is needed to push it forward?

First, an inductive comparative research agenda requires a multiplicity of thick descriptions of slavery regimes. Research is necessary into practices and regulations for each case, integrating multiple source-types through a method of "triangulation" that contrasts "intensive observations" with "external analyses" and "local narratives." Second, we must account for the connections through patterns of coerced mobility for each case study region, especially via the slave trade, but including also other forms such as tribute,

\footnotetext{
98 Lovejoy, Transformations; Dalrymple-Smith, Commercial Transitions.

99 Ward, "Slavery."

100 Van Rossum et al., Testimonies of Enslavement.

101 Vink, "World's Oldest Trade."

102 Schulte Nordholt, Spell of Power.

103 For West Africa, see e.g., Lovejoy, Transformations; P. Manning, Slavery and African Life: Occidental, Oriental, and African Slave Trades (Cambridge, 1990); and Dalrymple-Smith, Commercial Transitions. For the Western Indian Ocean, see Alpers, "French Slave Trade"; Joseph E. Harris, The African Presence in Asia: Consequences of the East African Slave Trade (Evanston, 1971); and Thomas Vernet, "Slave Trade and Slavery on the Swahili Coast (15001750)," in B. A. Mirzai, I. M. Montana, and P. Lovejoy, Slavery, Islam and Diaspora (Trenton, 2009), 37-76.

104 Ward, "Slavery"; Reid, "Slavery so Gentle."
} 
deportation, and war. This has already been developed for the Atlantic, but will require large efforts elsewhere, with new initiatives only recently started for the Indian Ocean, the Indonesian Archipelago, and China. ${ }^{105}$ Third, for each case study, the wider local and regional socio-political and economic context must be accounted for. Only then can we, fourthly, begin to analyze and compare the specific trajectories of slavery regimes and their roles in the long-term global transformation of slavery.

The development of the first steps, especially-thick-descriptions of regimes of slavery, their development over time, and their relation to external impacts and connections - requires a heightened attention to methodologies, the possibilities and limitations of sources, and how best to develop thick-description case studies in largely non-European historical contexts. Let me expand on this a bit. As stated, the study of slavery and coerced-labor regimes entails exploring how social relations are shaped. The norms, institutions, and practices that shaped slavery and coercive regimes were enacted, enforced, and contested at the level of everyday life. The different key elements for thick descriptions of slavery regimes (in the integrated framework) are therefore best examined through sources that provide researchers with observations on historical everyday realities. ${ }^{106}$ An example is court records and their rich investigations and testimonies, which can be used to explore dynamics within, for example, the realm of the Dutch Asian and Atlantic empire, ${ }^{107}$ and even those beyond the borders of colonial societies, for example the control of enslaved people's mobility as indicative of the characteristics of different forms of slavery. ${ }^{108}$

Unfortunately, for many societies outside of or on the fringe of European empires, like in the Indian Ocean and the Indonesian Archipelago, few quotidian written records have been preserved. ${ }^{109}$ Many valuable local written sources from non-European societies are of course available, ranging from legal texts and contracts to chronicles and histories, but most do not record practices at this crucial level of everyday life. This lack of readily available local sources detailing the everyday dynamics of slavery and coerced labor regimes might help explain the relatively late development of academic interest in the topic, and why older assumptions with regard to the characteristics of "Asian" slavery as "mild" and "local" have remained

105 Examples are the Exploring Slave Trade in Asia project (https://iisg.amsterdam/nl/research/ projects/slave-trade-asia); and the Human Trafficking and Slaving in China project (https://chts. hypotheses.org/author/chts).

106 C. Anderson, Subaltern Lives: Biographies of Colonialism in the Indian Ocean World, 1790-1920 (Cambridge, 2012).

107 For example, in the Resilient Diversity project, Leiden University and IISH, 2017-2022.

108 Van Rossum et al., Testimonies.

109 Manjusha Kuruppath, "In the Company of Global History," BMGN-Low Countries Historical Review 134, 2 (2019): 103-14. 
unchallenged for so long. This demonstrates one danger of over-reliance on just one type of source: it is difficult to counterweigh its inherent biases. Like colonial records, ${ }^{110}$ South and Southeast Asian court chronicles and legal texts cannot be considered neutral, unproblematic sources. ${ }^{111}$

I therefore suggest a strategy of "triangulation" as a way forward that can help us to overcome these obstacles by optimizing the use of the many source types available for this region and period. This triangulation strategy should bring together and balance different types of material offering "local narratives," "intensive observations," and "external analyses." In this way, we can offset the limitations of relying solely on either colonial or local sources. It has the added advantage of providing different perspectives that together can enrich and improve the thick descriptions of slavery regimes as well as the analysis of coerced mobility and the socio-political context.

A crucial factor in the success of such a strategy will be the availability, accessibility, and quality or richness of source materials. Ideally, all three source types will be present and accessible, but sometimes they will not be. An initial, rough inventory of types and coverage of source material is presented here to explore the limitations of the proposed method. ${ }^{112}$ Based on this, we can conclude that the availability of specific "key" sources seems ensured for many regions, even those typically considered poor in terms of source materials, and that there seems to be a sometimes random, but often relatively rich variety of material available from additional source types. Underlining the importance of European archival material, it becomes clear

110 A. Stoler, Along the Archival Grain: Epistemic Anxieties and Colonial Common Sense (Princeton, 2009).

111 Gaynor, Intertidal History.

112 A short overview of this inventory: (1) sources for "external analyses": (a) Travel accounts (translated and untranslated: Arabic, Persian, Portuguese, Dutch, French, twelfth-eighteenth centuries): published and translations series, e.g., KNAW-Collection; L'Honoré Naber, Reisebeschreibungen; Linschoten-series; Hakluyt Society; Ferrand, Instructions. (b) Political or geographic-cultural analyses (especially Portuguese, Dutch, and missionary texts, sixteentheighteenth centuries, and also later anthropological studies): Archival series, especially Nationaal Archief [NA], 1.04.02 (VOC), OBP-series; 1.10.78 (Sweers); Goa Archives, letters and reports (Livros das Monções do Reino), published series overview: Pearson 1981; Archivum Romanum Societatis Iesu [ARSI], "Old Society," (annual) letters received. Published sources, e.g., Van Vliet (Siam), Visscher (Malabar); NEHA-merchant guides. (2) Sources for "intensive observations": (a) European administrative series (especially Dutch, Portuguese, also Danish, French, and English, sixteenth-eighteenth centuries): archival series: NA, VOC, OBP; Arsip Nasional Republik Indonesia, VOC-archives; Goa Archives; Archives Nationales d'Outre Mer; Rigsarkivet, Ostindisk and Asiatisk Kompagni; British Library, India Office Records. (b) European legal records and inquiries (especially Dutch, sixteenth-eighteenth centuries): archival series: NA, VOC, OBP; Arsip Nasional Republik Indonesia. (c) Local non-European everyday source material (translated and untranslated sources, fifteenth-eighteenth centuries): published sources, e.g., Hikayat Patani; see also Creese 2009; Central Record Office Ernakulam. (3) Sources on "Local narratives": (a) Southeast and South Asian historical accounts (translated and untranslated sources, fifteenth-eighteenth centuries): published and translated court narratives, chronicles, and histories. See also Gaynor, Intertidal History. 
that for many regions "key" sources are available at some level to provide "intensive observations," especially through the Dutch East India Company administrations (in the Overgekomen Brieven en Papieren) and Portuguese archival material (for example, for Bengal, Sulawesi, Malabar, Coromandel, Nias, and the Lesser Sunda Islands region). Sources of "external analyses" are available through European and translated non-European travel accounts, missionary sources, and contemporary political or geographic-cultural treatises in Dutch, Portuguese, and other European languages. And, to conclude, for many regions there are also sources that either provide "local narratives," local or European legal sources, and/or anthropological studies.

Finally, it is important to discuss some challenges of the proposed method. First of all, any comparison of sources for different case studies entails a great deal more research and analytical work than does a case study based on a single set of sources. Second, while a source-intensive triangulation method is pivotal for advancing a comparative agenda, the variety of source material will require both a wide range of language skills and intensive international collaboration. This will, in turn, help with the third point, that a multi-comparative approach helps to avoid the trap of understanding cases by comparing only one or two (formulating characteristics of cases only with dichotomies). Fourth, it will be important to bring in the multitude of historiographies existing for different regions across the globe, which offer valuable insights into the wider context of political, cultural, and (to a lesser extent) social and economic history for the precolonial and colonial periods. For some regions, there are extensive historiographies that deal with the history of slavery and other coercive regimes. Yet, it is crucial to note that many existing studies that relied on older interpretations of Asian "local" and "mild" bondage or slavery developed their arguments based on a single source type. Others simply did not have slavery as their main interest. The wealth of in-depth, source-based case studies for this project is therefore not only crucial for a global comparative agenda, but also to overcome previous conceptualizations of "othering"- that is, the "special" status of "smaller" slaveries. This again emphasizes that only a truly global and inductive comparative-connecting approach, carried out via international collaborations that bridge linguistic, regional, and historiographic divisions, will enable a breakthrough in the academic and public understanding of the history of slavery.

\section{TO CONCLUDE}

I have argued here that we need to move beyond the "Atlantic" and "formal" bias in global slavery studies and develop a better understanding of the long-term global transformations of slavery through the variety of slavery regime trajectories. I have proposed several ways forward. First, we should focus on 
understanding the persistence of slavery beyond its classic and legal forms. That is, we need to revisit the historical transformations of slavery through a wider spectrum of trajectories, based on an improved conceptual understanding of what slavery is, by accounting for its adaptable yet universal character.

This implies that we should, as Zeuske points out, substantially expand the body of empirical observations on cases, especially outside the Atlantic and most notably in the Indian Ocean and Indonesian Archipelago worlds, where different slavery regimes existed and developed in interaction.

The cases of informal slavery regimes should at the same time be connected to the wider body of existing scholarship on slavery and its transformations of Atlantic, and other more intensely studied formal slavery regimes across the globe both during the period of legal slave trading and after abolition. Rather than employing multiple, diverging frameworks, we need to work toward an integrated analytical framework that will allow analysis of the trajectories of slavery regimes in their highly diverse manifestations, both formal and informal.

Finally, the integrated framework proposed here can be used for a collaborative global-historical research agenda that focuses on not only comparisons of different regimes, but also connections and interactions between them. Taking in the myriad of cases of slavery regimes throughout the history of the world in such a systematic and bottom-up exploration will renew our understandings of slavery and its long-term global historical transformations. 
Abstract: This article argues that we need to move beyond the "Atlantic" and "formal" bias in our understanding of the history of slavery. It explores ways forward toward developing a better understanding of the long-term global transformations of slavery. Firstly, it claims we should revisit the historical and contemporary development of slavery by adopting a wider scope that accounts for the adaptable and persistent character of different forms of slavery. Secondly, it stresses the importance of substantially expanding the body of empirical observations on trajectories of slavery regimes, especially outside the Atlantic, and most notable in the Indian Ocean and Indonesian Archipelago worlds, where different slavery regimes existed and developed in interaction. Thirdly, it proposes an integrated analytical framework that will overcome the current fragmentation of research perspectives and allow for a more comparative analysis of the trajectories of slavery regimes in their highly diverse formal and especially informal manifestations. Fourth, the article shows how an integrated framework will enable a collaborative research agenda that focuses not only on comparisons, but also on connections and interactions. It calls for a closer integration of the histories of informal slavery regimes into the wider body of existing scholarship on slavery and its transformations in the Atlantic and other more intensely studied formal slavery regimes. In this way, we can renew and extend our understandings of slavery's long-term, global transformations.

Key words: slavery, slave trade, historical transformation, comparisons, connections, global history, Atlantic world, Indian Ocean, Indonesian Archipelago 